\title{
The hemX gene of the Bacillus subtilis hemAXCDBL operon encodes a membrane protein, negatively affecting the steady-state cellular concentration of HemA (glutamyl-tRNA reductase)
}

\author{
Ingrid Schröder, $†$ Per Johansson, Lars Rutberg and Lars Hederstedt
}

\author{
Author for correspondence: Lars Hederstedt. Tel: +46 108622. Fax: +46 157839.
}

Department of

Microbiology, Lund

University, Sölvegatan 21 ,

S-223 62 Lund, Sweden

\begin{abstract}
The Bacillus subtilis hemAXCDBL operon encodes enzymes for the biosynthesis of uroporphyrinogen III from glutamyl-tRNA. The function of the hemX gene product was studied in this work. The deduced amino acid sequence suggests HemX to be an integral $32 \mathrm{kDa}$ membrane protein. This was confirmed by experiments using Escherichia coli minicells and hemX-phoA gene fusions. Deletion of the hemX gene from the Bacillus subtilis chromosome demonstrated that this gene is not required for haem synthesis. However, the deletion strain was found to overexpress the hemA gene product, glutamyltRNA reductase. A combination of results obtained with $B$. subtilis hemA and hemX in Escherichia coli and Bacillus subtilis shows that HemX negatively affects the steady-state cellular concentration of HemA protein. The mechanism by which HemX affects the HemA concentration is unclear.
\end{abstract}

Keywords : 5-aminolaevulinic acid biosynthesis, protohaem IX synthesis, Bacillus subtilis, bem genes

\section{INTRODUCTION}

5-Aminolaevulinic acid (ALA) is an early precursor in the synthesis of haem. Eight molecules of ALA are used for the sunthesis of one protohaem IX molecule in a sevenstep pathway. Little is known about regulation of ALA and protohaem IX synthesis in bacteria. In the Grampositive strictly aerobic bacterium Bacillus subtilis, ALA is synthesized from glutamate by the $C_{5}$ pathway (O'Neill $e t$ al., 1989). This pathway is found in plants and algae (Beale \& Weinstein, 1990) and in most bacteria, e.g. Escherichia coli (O'Neill et al., 1989), Salmonella typhimurium (Elliott, 1989), Clostridium thermoaceticum (Oh-hama et al., 1988) and Methanobacterium thermoautotrophicum (Friedmann et al., 1987). The pathway involves three enzymic steps. Glutamate is first activated by ligation to tRNA ${ }^{\mathrm{Glu}}$, a reaction catalysed by glutamyl-tRNA synthase (EC 6.1.1.17). The tRNA and the synthase are the same as used in protein synthesis (Jahn et al., 1992). The glutamyltRNA is then reduced by glutamyl-tRNA reductase in an

†Present address: Russell Grimwade School of Biochemistry, University of Melbourne, Parkville, Victoria 3052, Australia.

Abbreviations: ALA, 5-aminolaevulinic acid; Urolll, uroporphyrinogen III; GSA, glutamate 1-semialdehyde; ALP, alkaline phosphatase.
NADPH-dependent reaction to yield glutamate 1semialdehyde (GSA). In the last step a GSA aminotransferase (EC 5.4.3.8) converts GSA to ALA.

In $B$. subtilis there are two clusters of bem genes. The bem $A X C D B L$ operon, located at about $244^{\circ}$ on the chromosomal genetic map (Petricek et al., 1990; Hansson et al., 1991), encodes enzymes for the early steps of haem synthesis, i.e. the synthesis of ALA and uroporphyrinogen III (UroIII). The other cluster, the bemEHY operon at about $94^{\circ}$, encodes enzymes for late steps, i.e. UroIII to protohaem IX (Hansson \& Hederstedt, 1992). The bem $A$ and bemL genes encode glutamyl-tRNA reductase and GSA aminotransferase, respectively (Hansson $e t$ al., 1991; Schröder et al., 1992). The hemB, hem $C$ and hemD genes encode the three enzymes required for the synthesis of UroIII from ALA: porphobilinogen synthase (EC 4.3.1.8), hydroxymethylbilane synthase (EC 4.2.1.75) and UroIII synthase (EC 4.1.1.37), respectively (Petricek et al., 1990; Hansson et al., 1991).

The function of the bemX gene of the bem AXCDBL operon has not been elucidated. The $B$. subtilis strain $3 \mathrm{G} 18 \Delta 404 \mathrm{R}$ has the bem $A$ and be $m X$ genes deleted from the chromosome. If this strain is transformed with a plasmid containing bem $A$ it grows without supplemen- 
tation of ALA (Schröder et al., 1992). This shows that be $\mathrm{X}$ is not essential for the synthesis of UroIII from ALA. We have not found any apparent homologue to HemX in protein or DNA sequence databases. The bem $X$ gene has coding capacity for a protein of 276 amino acids $(32.0 \mathrm{kDa})$ (Petricek et al., 1990). Inspection of the deduced amino acid sequence reveals two features: several uncharged segments of more than 18 amino acid residues and four consecutive lysine residues in the middle part of the deduced polypeptide. The length and amino acid composition of some of the uncharged segments indicate that they could be transmembrane segments, suggesting that HemX is an integral membrane protein (see Fig. 1a).

In this work we will show that HemX is a membranebound protein. Furthermore, although HemX is not essential for any step in tetrapyrrole synthesis, our experiments indicate that it plays a role in controlling the steady-state concentration of HemA in the cell.

\section{METHODS}

Bacterial strains and plasmids. These are listed in Table 1.

Media and growth of bacteria. E. coli strains were grown on LA plates or in LB medium (Sambrook et al., 1989); M63 minimal medium (Pardee et al., 1959) was used in the experiments on turnover of HemA in E. coli. B. subtilis strains were grown on Tryptose Blood Agar Base (Difco), in Spizizen's minimal medium (Spizizen, 1958) with required amino acids added at $25 \mathrm{mg} \mathrm{l}^{-1}$, in LB or in nutrient sporulation medium with phosphate (NSMP) (Fortnagel \& Freese, 1968). To media containing haemin $\left(2.5 \mathrm{mg} \mathrm{l}^{-1}\right)$, cysteine $\left(20 \mathrm{mg} \mathrm{l}^{-1}\right)$ and $0.5 \%$ $(\mathrm{w} / \mathrm{v})$ bovine serum albumin fraction $\mathrm{V}$ (Sigma) were also added. Stock solutions of haemin were prepared as described previously (Petricek et al., 1990). The following antibiotics and concentrations were used: phleomycin (E. coli, $10 \mathrm{mg} \mathrm{l}^{-\mathbf{1}} ; B$. subtilis, $\left.0.4 \mathrm{mg}^{-1}\right)$, ampicillin $\left(50 \mathrm{mg} \mathrm{l}^{-1}\right)$, chloramphenicol $(E$. coli, $20 \mathrm{mg} \mathrm{l}^{-1}$; B. subtilis, $\left.5 \mathrm{mg} \mathrm{l}^{-1}\right)$, kanamycin $\left(30 \mathrm{mg} \mathrm{l}^{-1}\right.$ or $300 \mathrm{mg} \mathrm{l}^{-1}$ in the initial screening of $p h o A$ gene fusions). Competent $E$. coli and $B$. subtilis were prepared as previously described (Mandel \& Higa, 1979; Arwert \& Venema, 1973).

DNA techniques. Large- and small-scale preparations of plasmid DNA were done as described by Ish-Horowicz \& Burke (1981) or using the MagicMinipreps DNA purification system (Promega); $B$. subtilis cells were treated with lysozyme $\left(5 \mathrm{mg} \mathrm{l}^{-1}\right.$ at $37^{\circ} \mathrm{C}$ for $30 \mathrm{~min}$ ) prior to the alkaline lysis. B. subtilis chromosomal DNA was extracted by the procedure of Marmur (1961). General DNA techniques were as described by Sambrook et al., (1989). Southern blot analysis was done with digoxigenin-labelled probe DNA using the DNA Labelling and Detection Kit from Boehringer. DNA sequence analysis was done by the dideoxy-chain-termination method (Sanger et al., 1977), using modified T7 DNA polymerase (Sequenase version II ; [S Biochemical) and $\left[{ }^{35} \mathrm{~S}\right] \mathrm{dATP} \alpha \mathrm{S}$ (Amersham) on doublestranded DNA.

Analysis of plasmid-encoded gene products. E. coli D07 is a minicell-producing strain which was used to analyse plasmidencoded proteins. The minicells were purified from early stationary phase cultures as described by Dougan \& Kehoe (1984). Labelling medium for the E. coli D07 minicells consisted of $5 \mathrm{ml}$ Methionine Assay Medium (Difco), $15 \mathrm{ml} \mathrm{M9}$ (Sambrook et al., 1989), $0.4 \mathrm{ml} 50 \%$ (w/v) glucose, pyridoxine $\left(0.025 \mathrm{ml} \mathrm{l}^{-1}\right)$, and adenine $\left.\left(0.025 \mathrm{mg} \mathrm{l}^{-1}\right) ; 10 \mu \mathrm{Ci} \mathrm{L}^{-}-{ }^{35} \mathrm{~S}\right] \mathrm{methio}-$ nine $\left(800 \mathrm{Ci} \mathrm{mmol}^{-1}\right.$, Amersham; $\left.1 \mathrm{Ci}=37 \mathrm{GBq}\right)$ was used to label every $0.5 \mathrm{ml}$ of the minicells. The labelling of proteins with $\left[{ }^{35} \mathrm{~S}\right]$ methionine was done according to Dougan \& Kehoe (1984). After labelling for $2 \mathrm{~h}$ at $37^{\circ} \mathrm{C}, 0.5 \mathrm{mg}$ non-radioactive methionine was added and the cells were incubated for another $5 \mathrm{~min}$. The labelled minicells were centrifuged at $5000 \mathrm{~g}$ for $10 \mathrm{~min}$ at room temperature, washed twice with $50 \mathrm{mM}$ Tris $/ \mathrm{HCl} \mathrm{pH} 8.0$ and resuspended in $0.25 \mathrm{ml} 10 \mathrm{mM}$ Tris/ $\mathrm{HCl}$ $\mathrm{pH} 8 \cdot 0$. The cells were broken by sonication and the membranes were separated from the soluble fraction by centrifugation at $100000 \mathrm{~g}$ for $60 \mathrm{~min}$ at $4{ }^{\circ} \mathrm{C}$.

Construction of a $B$. subtilis hemX deletion-substitution mutant. The B. subtilis mutant $3 \mathrm{G} 18 \Delta \mathrm{HemX}$ was constructed by transforming $B$. subtilis 3 G18 with pLUUII linearized by $S_{c a} I$ cleavage. Plasmid pLUUII (Table 1) consists of pUC18 containing a ble gene flanked by bem $A$ chromosomal DNA (bp 90-1656) and be $X C$ DNA (bp 2144-2809), basepair numbering according to Petricek et al. (1990). Deletion mutants were selected on plates containing phleomycin and haemin.

Generation and analysis of PhoA fusions. E. coli CC118/ pLUP513 was infected with $\lambda::^{\prime} \operatorname{Tn} p h o A-1$ and selection for transfectants was made on LA-plates supplemented with antibiotics and 5-bromo-4-chloro-3-indolylphosphate- $p$ toluidine (X-Phosphate) $\left(40 \mathrm{mg} \mathrm{l}^{-1}\right)$ as described by Manoil \& Beckwith (1985). Plasmid DNA of $\mathrm{PhoA}^{+}$clones was analysed by cleavage with restriction enzymes and the fusion points were determined by nucleotide sequence analysis using an internal 17 mer primer complementary to pho $A$ : $5^{\prime}$-CACGCAGAGCGG CAGTC-3'. The stable bem $X-p h o A$ fusions were subcloned into pUC18 using the BamHI-SalGI site. The transposase and kanamycin-resistance genes of $\lambda:: \operatorname{Tn} p h o A-1$ were thereby eliminated. Alkaline phosphatase activity was measured as described by Von Wachenfeldt \& Hederstedt (1990).

Preparation of cell extracts for determination of HemA. $B$. subtilis strains were grown overnight and then used to inoculate $100 \mathrm{ml}$ fresh medium in 1 litre indented flasks to an $\mathrm{OD}_{600}$ of 0.05 . The cultures were grown at $37^{\circ} \mathrm{C}(200$ r.p.m.) and harvested at different times during growth or when entering stationary phase. The cells were sedimented by centrifugation at $6000 \mathrm{~g}$ for $10 \mathrm{~min}$ at $4{ }^{\circ} \mathrm{C}$, washed once in $50 \mathrm{mM}$ Tris $/ \mathrm{HCl}$, $\mathrm{pH} 7.2$ and resuspended in $1 \mathrm{ml}$ of the same buffer containing $0.1 \mathrm{mg}$ lysozyme. The cells were incubated at $37^{\circ} \mathrm{C}$ for $30 \mathrm{~min}$ and then sonicated while chilled on ice. Whole-cell extract was the supernatant obtained after centrifugation at $3000 \mathrm{~g}$ for $10 \mathrm{~min}$ at $4{ }^{\circ} \mathrm{C}$. E. coli strains were grown in $100 \mathrm{ml}$ medium in $500 \mathrm{ml}$ flasks or in 1 litre medium in 5 litre flasks at $37^{\circ} \mathrm{C}(200$ r.p.m.). The cells were harvested and whole-cell extracts were prepared as described above except for the lysozyme treatment.

Turnover of B. subtilis HemA in E. coli. E. coli MM294 carrying pHP13, pHEMA2 or pHEMAX was grown aerobically at $37^{\circ} \mathrm{C}$ in M63 minimal medium supplemented with 18 of the common amino acids (methionine and cysteine were excluded). When the cultures reached mid-exponential growth $\left(\mathrm{OD}_{600}=1\right)$ they were pulsed with $10 \mu \mathrm{Ci} \mathrm{ml} l^{-1}$ L- $\left[{ }^{35} \mathrm{~S}\right]$ methionine $(1500 \mathrm{Ci}$ $\mathrm{mmol}^{-1}$, Amersham) and $30 \mathrm{~min}$ later a chase of $5 \mu \mathrm{g} \mathrm{ml}^{-1}$ unlabelled methionine was added. Samples were taken at intervals from the cultures. Preparation of cell extracts and immunoprecipitation of HemA followed the procedures described by Anderson \& Blobel (1983) using polyvalent rabbit anti-HemA antibodies (raised against denatured Hem $\mathrm{A}$ ) bound to protein A-Sepharose CL-4B (Pharmacia). Immunoabsorbed proteins were eluted by incubation at $55^{\circ} \mathrm{C}$ for $20 \mathrm{~min}$, in the presence of SDS-PAGE preparation buffer excluding dithiothreitol. The eluted proteins were analysed by SDS-PAGE and labelled protein quantified using a Phosphoimager (Fuji). Titrations were done to assure that antibodies against HemA and protein A-Sepharose were in excess relative to $\mathrm{HemA}$ 
Table 1. Bacterial strains and plasmids

\begin{tabular}{|c|c|c|}
\hline Strain or plasmic & Description & Reference \\
\hline \multicolumn{3}{|l|}{ Strains } \\
\hline \multicolumn{3}{|l|}{ B. subtilis } \\
\hline $3(; 18$ & ade met $\operatorname{trp} C 2$ & $\begin{array}{l}\text { G. Venema, University of } \\
\text { Groningen }\end{array}$ \\
\hline $3 G ; 18 \Delta 404 R$ & ade met $\operatorname{trp} C 2 \Delta$ bem $A X::$ cat & Petricek et al. (1990) \\
\hline $3 G ; 18 \Delta \operatorname{HemX}$ & ade met $\operatorname{trp} C 2 \Delta$ bem $X:$ : ble & This work \\
\hline \multicolumn{3}{|l|}{ E. coli } \\
\hline JM109 & $\begin{array}{l}\operatorname{rec} A 1 \text { supE } 44 \text { end } A 1 \text { bsd } 17 \text { gyr } A 96 \text { rel } A 1 \text { thi } \\
\Delta(\text { lac-pro } A B) \mathrm{F}^{\prime}\left[\operatorname{traD} 36 \text { pro } A B^{+} \text {lac } I^{q}\right. \\
\text { lacZ } \Delta M 15]\end{array}$ & Yanisch-Perron et al. (1985) \\
\hline $\mathrm{D} 07$ & $\mathrm{~F}^{-}$purE bis ilv $p d x C$ met rpsL ton $A$ min $B x y l$ & Levy et al. (1977) \\
\hline CC118 & $\begin{array}{l}\text { araD139 } \Delta(\text { ara leu }) 7697 \Delta l a c X 74 \text { pho } A \Delta 20 \text { galE } \\
\text { galK thi rpsE rpoB argE } E_{\mathrm{am}} \operatorname{rec} A 1\end{array}$ & Manoil \& Beckwith (1985) \\
\hline MM294 & end $A 1$ thi pro bsdR 17 supE 44 & $\begin{array}{l}\text { L.-O. Hedén, University of } \\
\text { Lund }\end{array}$ \\
\hline \multicolumn{3}{|l|}{ Plasmids } \\
\hline pUC18 & $A p^{r}$ & Yanisch-Perron et al. (1985) \\
\hline puC19 & $A p^{r}$ & Yanisch-Perron et al. (1985) \\
\hline pHP13 & $\mathrm{Cm}^{\mathrm{r}} \mathrm{Em}^{\mathrm{r}}$ & Haima et al. (1987) \\
\hline $\mathrm{pACYC} 177$ & $A p^{r} K m^{r}$ & Chang \& Cohen (1978) \\
\hline pBLE1 & $\mathrm{Ap}^{\mathrm{r}} \mathrm{Pm}^{\mathrm{r}} ;$ ble in $\mathrm{pUC} 18$ & Fridén \& Hederstedt (1990) \\
\hline pI.UP512 & $\operatorname{bem} A$ in $\mathrm{pUC} 19$ & Petricek et al. $(1990)$ \\
\hline pLUP513 & bem $X$ in $\mathrm{pUC19}$ & Petricek et al. (1990) \\
\hline pLCP515 & pLUP513 deleted of the first 51 bp of hem $X$ & Petricek et al. (1990) \\
\hline pLLP330 & bem $A$, bem $X$, bem $C$ in pHV32 & Petricek et al. (1990) \\
\hline pLUUII & $\begin{array}{l}0.66 \mathrm{kbp} \text { HindIII fragment from pLUP515 } \\
\text { and } 1.6 \mathrm{kbp} \text { EcoRI fragment from pLUP } 512 \text {, } \\
\text { in pBLE1 }\end{array}$ & This work \\
\hline PHEMAX & $\begin{array}{l}3.6 \mathrm{kbp} \text { Bam HI-EcoRI bem } A X \text { fragment from } \\
\text { pLUP330, in pHP13 }\end{array}$ & This work \\
\hline pHEMA2 & $\begin{array}{l}1 \cdot 4 \mathrm{kbp} M l u \mathrm{I}-\mathrm{E} c o \mathrm{RI} \text { hem } X \text { fragment deleted } \\
\text { from } \mathrm{pHEMAX}\end{array}$ & This work \\
\hline $\mathrm{pHH} \mathrm{MX}$ & $\begin{array}{l}654 \text { bp bem } A \text { in-frame } S_{a} / \text { GI fragment deleted } \\
\text { from } \mathrm{pHEMAX}\end{array}$ & This work \\
\hline pHEMX513 & $\begin{array}{l}1.9 \mathrm{kbp} \text { BamHI-EcoRI bemX fragment from } \\
\text { pLUP513 in BamHI-EcoRI site of pHP13 }\end{array}$ & This work \\
\hline pAHEMA2 & $\begin{array}{l}2 \cdot 2 \mathrm{kbp} B a m \mathrm{HI}-\text { FspI bem } A \text { fragment from } \\
\text { pHEMA2 in Bam HI-HindII site of } \\
\text { pACYC177 }\end{array}$ & This work \\
\hline
\end{tabular}

antigen. Extracts of MM294/pHP13 served as negative control, i.e. lacked HemA antigen.

Other methods. SDS-PAGE was done according to Neville (1971). Proteins were stained with Coomassie Brilliant Blue R250, followed by autoradiography of the gel when required. The following proteins were used as markers: $\beta$-galactosidase $(130 \mathrm{kDa}), \mathrm{BSA}(68 \mathrm{kDa})$, catalase $(58 \mathrm{kDa})$, fumarase $(48 \mathrm{kDa})$, carbonic anhydrase $(29 \mathrm{kDa})$ and myoglobin $(17 \mathrm{kDa})$. Antiserum against $E$. coli alkaline phosphatase (Pharmacia LKB Biotechnology) was prepared from rabbits. Preparation of antisera against native and denatured $\operatorname{HemA}$, and immunoblotting, have been described previously (Schröder et al., 1992). Rocket immunoelectrophoresis was done as described by Rutberg et al. (1978) and the relative amounts of antigen were determined from the areas under the precipitate arcs (Owen, 1981). The antiserum directed against native HemA was absorbed with cell extract from an E. coli HemA mutant strain (AN344) (MacGregor, 1976) before being used to determine the amount of B. subtilis HemA expressed in E. coli JM109. Protein was determined by the Lowry method.

\section{RESULTS}

\section{HemX is membrane bound}

The calculated molecular mass of HemX is $32.0 \mathrm{kDa}$. Hydropathy plots of the predicted HemX amino acid sequence indicate several hydrophobic stretches, with up to seven possible membrane-spanning segments (Fig. 1a). A protein of $26 \mathrm{kDa}$ encoded by hem $X$ has been detected using an $E$. coli in vitro transcription-translation system (Petricek et al., 1990). To determine the size of HemX 


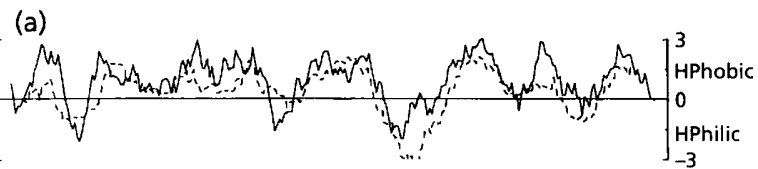

(b)
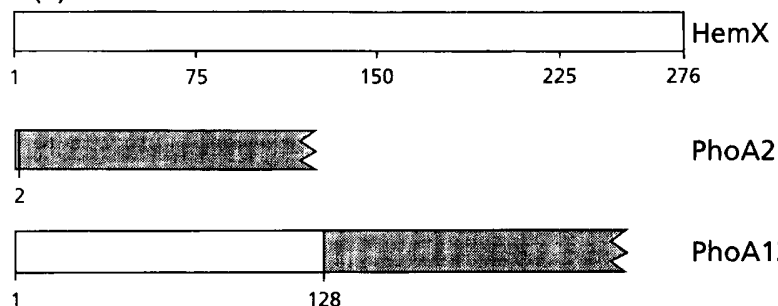

PhoA128

(c)

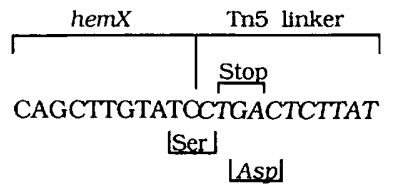

DNA sequence

GIn Leu Val Ser Asp Ser Tyr

Amino acid

Fig. 1. Hydropathy plots of the $B$. subtilis hem $X$ gene product (a), products of hemX and hemX-phoA gene fusions (b), and the hemX-phoA out-of-frame fusion point in pPHOA128 (c). (a) The GCG sequence analysis software package, version 7 (Devereux et al., 1984) was used to generate the hydropathy plots; a window of 9 was used. The continuous line represents the Kyte/Doolittle hydrophobicity plot and the dashed line the Goldman/Engelman/Steiz plot. (b) Schematic drawings of the deduced primary structures of wild-type $\mathrm{HemX}$ and two HemX-PhoA fusion proteins. The numbers refer to residues in HemX. The shaded parts represent PhoA sequences. (c) Close-up of the fusion point in the PhoA128 hybrid protein and the corresponding nucleotide sequence (the non-coding strand is shown).

synthesized in vivo and to analyse the cell localization of the bem $X$ gene product, we made use of an E. coli minicell system. E. coli D07 was transformed with pLUP513 (pUC19 containing bem X under the lac promoter) (see Fig. 2c). As controls, E. coli D07 was also transformed with pLUP512 (pUC19 containing the bem $A$ gene) and pUC19. Minicells from these transformants predominantly contain plasmid DNA and plasmid-encoded proteins can be identified after labelling with $\left[{ }^{35} \mathrm{~S}\right]$ methionine. We have previously shown that bem $A$ encodes a soluble protein of $50 \mathrm{kDa}$ (Schröder et al., 1992). Analysis by SDS-PAGE revealed that a $26 \mathrm{kDa}$ polypeptide is expressed from pLUP513 in minicells. This polypeptide is not expressed from pUC19 or pLUP512 (Fig. 3). We conclude that this polypeptide is the bem $X$ gene product. Fractionation of labelled minicells showed that the $26 \mathrm{kDa} H e m X$ polypeptide copurifies with the particulate (membrane) fraction, whereas the $50 \mathrm{kDa}$ bem $A$ gene product is found in the soluble fraction as expected (Fig. 3).

\section{HemX-PhoA fusion protein analysis}

To confirm that Hem $\mathrm{X}$ is an integral membrane protein and to analyse its topology we used the pho $A$ fusion system developed by Manoil \& Beckwith (1985). This

(a)

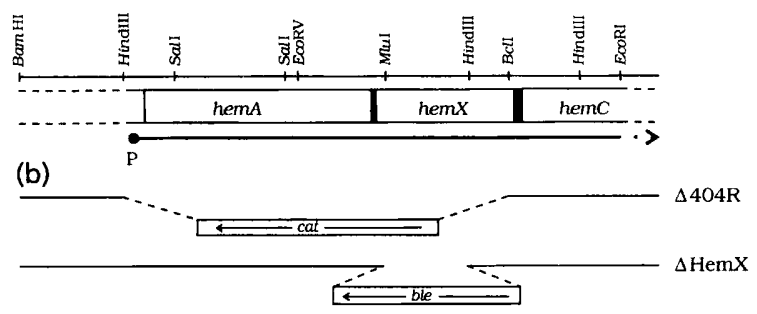

(c)

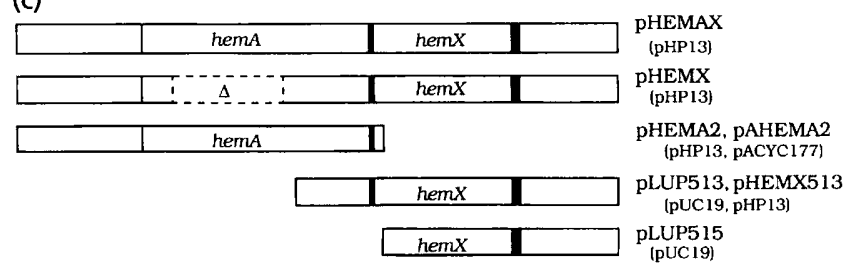

Fig. 2. Genetic map of the proximal part of the $B$. subtilis hemAXCDBL operon (a), deletion-substitutions of hemX in the chromosome of two different $B$. subtilis mutants (b), and DNA fragments present in different plasmids (c). (a) $P$ indicates the location of the hemAXCDBL promoter; the restriction enzyme sites indicated are the ones which were used in the construction of plasmids. (b) cat is a chloramphenicol-resistance gene and ble is a phleomycin-resistance gene which replaces the deleted region. (c) DNA fragments present in different plasmid constructs; the plasmid vector used is given underneath the name of each plasmid.

system is based on the fact that E. coli alkaline phosphatase (ALP), encoded by the pho $A$ gene, is a periplasmic enzyme which is active only after translocation from the cytoplasm to the periplasm. Translocation of ALP across the cytoplasmic membrane requires an $\mathrm{N}$-terminal signal sequence, which can be either a cleaved leader sequence or a transmembrane segment of a membrane protein where the C-terminal of the segment is oriented towards the periplasmic side.

Fusions between $B$. subtilis be $X$ and $p h o A$ were generated in vivo using phage $\lambda$ :: Tnpho $A$ and plasmid pLUP513 in E. coli CC118 ( $\triangle p h o A)$. This phage contains Tn5 with a modified $p h o A$ gene lacking its native signal sequence. Colonies with ALP activity were detected using plates containing the chromogenic substrate X-Phosphate. Six clones with bem $X$-pho $A$ fusions were identified among about 50 ALP-positive clones analysed. Sequencing across the fusion points in plasmids from these six clones revealed that two clones had an in-frame fusion point at a site corresponding to amino acid number two of Hem $\mathrm{X}$ (PhoA2, see Fig. 1b) and four clones had an out of frame fusion point at a site corresponding to amino acid 128 in HemX (PhoA128, see Fig. 1b, c).

The above two types of $h e m X-p h o A$ fusions were subcloned by transferring the $B a m \mathrm{HI}-X b o \mathrm{I}$ fragment from the original plasmids to the BamHI-SalGI site in pUC18. The resulting plasmids (pPHOA2 and pPHOA128) lack the major part of Tn5 encoding 


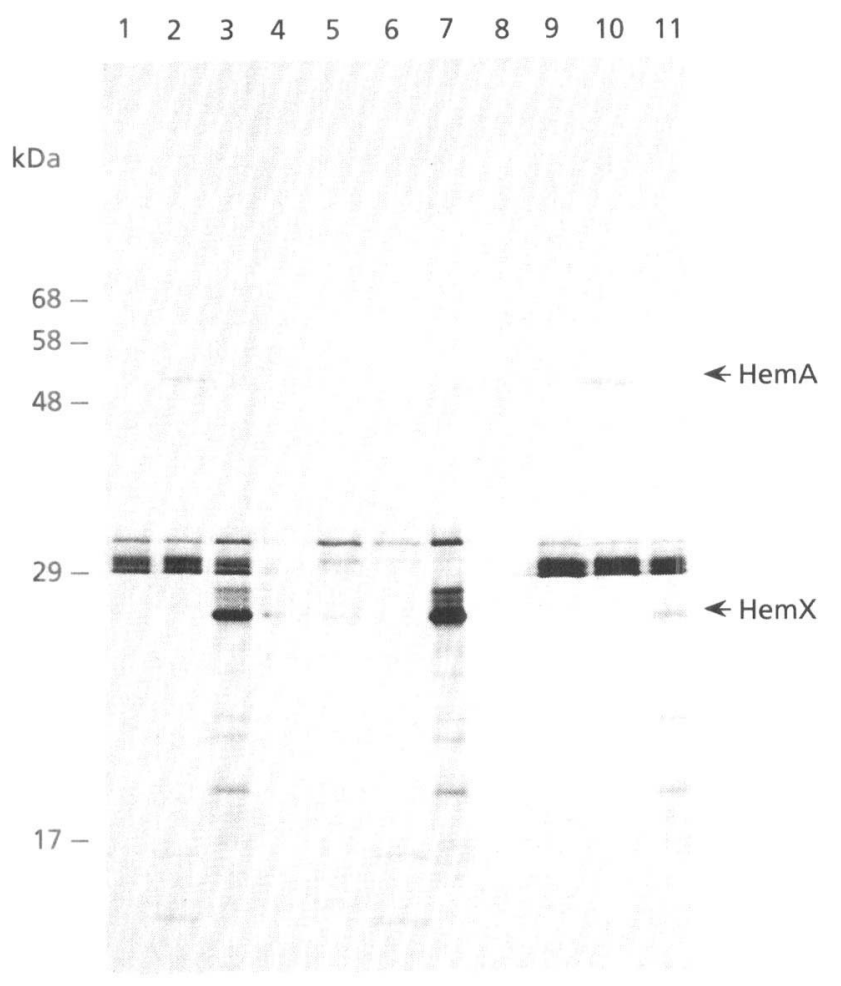

Fig. 3. Analysis of hemX and hemA expression in E. coli minicells. Proteins synthesized in minicells were labelled with [ ${ }^{35}$ S]methionine, then fractionated by SDS-PAGE $(12 \%, w / v)$ and detected by autoradiography (see Methods). Lanes 1, 5 and 9, E. coli D07/pUC19 (negative control); lanes 2, 6, and 10, E. coli D07/pLUP512 (hemA); lanes 3, 7 and 11, E. coli D07/pLUP513 (hem $X)$. Total lysates were loaded in lanes $1-3$, membrane fractions in lanes 5-7, and soluble fractions in lanes 9-11. Lanes 4 and 8 contain non-radioactive size-marker proteins.

kanamycin resistance and transposase functions. The gene fusions in the subclones were confirmed by sequence analysis.

Cells of E. coli CC118 containing pPHOA2 or pPHOA128 were analysed for PhoA protein and ALP activity. Cells containing pPHOA2 showed a 30-fold higher ALP activity than those containing pPHOA128. However, the

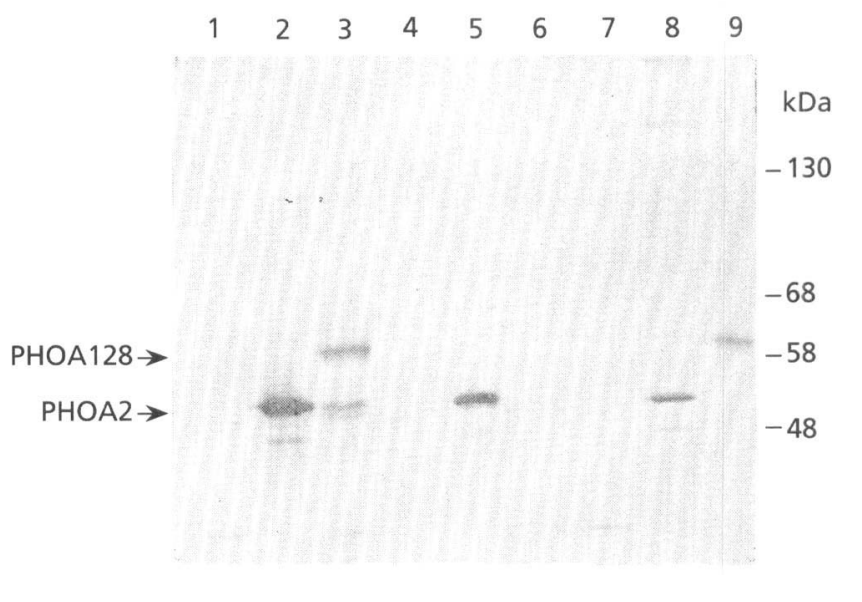

Fig. 4. Immunoblot analysis of HemX-PhoA fusion proteins. Whole cell lysate, periplasm and membrane fractions were prepared as described in Methods and analysed by SDS-PAGE $(10 \%, w / v)$ followed by Western blotting using antiserum directed against $E$. coli ALP. Lanes 1 and $3,10 \mu \mathrm{g}$ protein of whole-cell lysates from $E$. coli CC118 containing pUC18 and pPHOA 128 , respectively; lane $2,2 \mu \mathrm{g}$ protein of whole-cell lysate from $E$. coli $C C 118$ containing PPHOA2; lanes 4,5 and 6 , $1 \mu \mathrm{g}$ protein of periplasmic fraction from $E$. coli CC118 containing pUC18, pPHOA2 and pPHOA128, respectively; lanes 7,8 and $9,2.5 \mu \mathrm{g}$ protein of membrane fraction from $E$. coli CC118 containing pUC18, PPHOA2, and PPHOA128, respectively.

ALP activity of CC118/pPHOA128 was significantly above the background (CC118/pUC18) (Table 2). The ALP activity and PhoA hybrid protein of CC118/ pPHOA2 was found predominantly in the periplasm (Table 2, Fig. 4). The mass of this hybrid protein was $51 \mathrm{kDa}$ as determined by Western blot analysis using antiALP serum. This mass is close to that of purified $E$. coli ALP $(50 \mathrm{kDa})$, confirming that the hybrid protein only contains a few amino acids of HemX. In contrast, the ALP activity and PhoA hybrid protein of CC118/ pPHOA128 was localized in the membrane fraction (Table 2, Fig. 4). The mass of the HemX-PhoA protein expressed from pPHOA128 was approximately $60 \mathrm{kDa}$, which demonstrates that the out-of-frame fusion produces a full-length hybrid protein of a mass expected from an in-

Table 2. ALP activity of $E$. coli CC118 containing hemX-phoA gene fusions

ALP activities were measured as described in Methods and are given in $\mu \mathrm{mol}(\mathrm{mg} \text { protein })^{-1} \min ^{-1}$.

The mean values shown were derived from three independent experiments and are given with standard deviations.

\begin{tabular}{|lccc|}
\hline \multicolumn{4}{c|}{ ALP activity } \\
\cline { 2 - 4 } & CC118/pPHOA2 & CC118/pPHOA128 & CC118/pUC18 \\
\hline Permeabilized cells & $98 \pm 17$ & $4 \pm 2$ & $<0 \cdot 1$ \\
Periplasm & $87 \pm 8$ & $3 \pm 3$ & $<2$ \\
Membrane & $3 \pm 4$ & $35 \pm 14$ & $<1$ \\
\hline
\end{tabular}


Table 3. Steady-state relative concentrations of HemA in B. subtilis strains containing different plasmids

The different bacteria were grown in LB to early stationary phase $\left(\mathrm{OD}_{660}\right.$ about 2$)$ and whole-cell extracts were prepared as described in Methods. The relative amount of HemA antigen per mg total cell protein was determined by rocket immunoelectrophoresis using antiserum directed against native Hem A. The experiment was repeated three times; mean values with standard deviations are given. ND, Not determined.

\begin{tabular}{|c|c|c|c|}
\hline Plasmid & $\begin{array}{c}3 \text { G18 } \\
\text { (wild-type) }\end{array}$ & 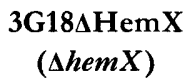 & $\begin{array}{c}\text { 3G18 } 4404 \mathrm{R} \\
(\Delta h e m A X)\end{array}$ \\
\hline pHP13 & $<0.005$ & $0 \cdot 2 \pm 0 \cdot 1$ & ND \\
\hline pHEMA2 & $1 \cdot 0 \pm 0 \cdot 4$ & $1 \cdot 7 \pm 0.8$ & $2 \cdot 5 \pm 1 \cdot 1$ \\
\hline pHEMAX & $0.8 \pm 0.5$ & $1 \cdot 1 \pm 0 \cdot 1$ & $0 \cdot 2 \pm 0 \cdot 1$ \\
\hline pHEMX & $<0.005$ & $<0.005$ & $<0.005$ \\
\hline
\end{tabular}

frame fusion at a position corresponding to about residue 128 of HemX. PhoA antigen of about $50 \mathrm{kDa}$ was found in extracts of CC118/pPHOA128. This $50 \mathrm{kDa}$ protein probably corresponds to $\mathrm{PhoA}$ protein proteolytically cleaved from the PhoA128 protein.

To confirm that PhoA128 is an integral membrane protein, the following experiment was done. The membrane fraction was isolated from CC118/pPHOA128. After centrifugation at $100000 \mathrm{~g}$ for $60 \mathrm{~min}$, more than $90 \%$ of both ALP activity and PhoA 128 protein was found in the pellet. When the membranes were treated with $2 \%(\mathrm{v} / \mathrm{v})$ Triton X-100 before centrifugation, more than $95 \%$ of ALP activity and PhoA128 protein was found in the supernatant fraction.

\section{Deletion of the hemX gene}

Part of the B. subtilis chromosomal bemX gene corresponding to amino acids 17 to 180 of $\mathrm{HemX}$ was deleted in strain 3G18 and replaced with a ble gene, generating strain $3 \mathrm{G} 18 \Delta \mathrm{HemX}$ (Fig. 2b). The deletion-substitution, confirmed by Southern blot analysis (data not shown), was designed such that bemCDBL would also in the mutant be transcribed from the promoter in front of bem $A$. Strain $3 G 18 \Delta \mathrm{HemX}$ does not have a growth requirement for ALA or haemin and it has the same growth rate as wild-type cells in broth and minimal medium (data not shown).

\section{hem $X$ affects the steady-state concentration of HemA}

The steady-state concentration of HemA in wild-type $B$. subtilis seems very low (Schröder et al., 1992). Surprisingly, a more than 15 -fold higher concentration of HemA was found in strain $3 \mathrm{G} 18 \Delta \mathrm{HemX}$ compared to strain 3G18 (Table 3). This difference in HemA cellular concentration was found in all media tested: NSMP, minimal medium containing $0.5 \%$ glucose and $0.05 \%$ Casamino acids, and minimal medium with $0.5 \%$ glutamate and $0.05 \%$ Casamino acids.

To study the effect of HemX on the cellular concentration of HemA protein, plasmids pHP13, pHEMX (contains hem $X$ ), pHEMA2 (contains bem $A$ ) and pHEMAX (contains both hem $A$ and hem $X$ ) were introduced into $B$. subtilis strains $3 \mathrm{G} 18$ and $3 \mathrm{G} 18 \Delta \mathrm{HemX}$ (Fig. 2). HemA protein was quantified in total cell extracts from these strains by rocket immunoelectrophoresis; the results obtained (Table 3) can be summarized as follows. No HemA protein was detected in $3 \mathrm{G} 18 \Delta \mathrm{HemX} / \mathrm{pHEMX}$, supporting the idea that HemX is involved in regulating HemA protein levels. Increasing the copy number of hem $A$ by placing it on a plasmid leads to increased levels of HemA protein also in the presence of the chromosomal copy of the hem $X$ gene. A significant effect of Hem X on the HemA protein concentration was not seem in strains $3 \mathrm{G} 18$ and $3 \mathrm{G} 18 \Delta \mathrm{HemX}$ when both hem $A$ and be $m X$ were present on the plasmid.

These experiments were extended by introducing pHEMX, pHEMA2 and PHEMAX into the B. subtilis strain 3G18 $404 \mathrm{R}$, which is deleted for both bem $A$ and bemX (Fig. 2b). This strain has a non-defined promoter allowing expression of bemCDBL and requires ALA for growth (Petricek et al., 1990). Strain 3G184404R carrying either pHEMA2 or pHEMAX does not require ALA for growth. The steady-state amount of HemA protein was 10-fold higher in 3G18 $4404 \mathrm{R} / \mathrm{pHEMA} 2$ compared to 3G18 404R/pHEMAX (Table 3).

A growth-phase-related quantification of HemA protein was next done for the following $B$. subtilis strains: $3 \mathrm{G} 18 \Delta$ HemX containing pHP13 or pHEMX (Fig. 5a), pHEMA2 or pHEMAX (Fig. 5b); 3 G18 containing pHEMA2 or pHEMAX (Fig. 5c); and 3G18 $404 \mathrm{R}$ containing pHEMA2 or pHEMAX (Fig. 5d). The results confirmed the data presented in Table 3 and indicated that the steady-state concentration of HemA protein in these strains is not dependent on the growth phase.

\section{Effect of HemX on B. subtilis HemA in E. coli}

B. subtilis HemA protein can be expressed at high levels from the bem $A$ gene with its native promoter in $E$. coli (Schröder et al., 1992). It was of interest to analyse if the effect of HemX on HemA protein can be observed also in a heterologous system like E. coli.

E. coli JM109 carrying pHEMA2 or pHEMAX was grown overnight in LB supplemented with chloramphenicol and the concentrations of HemA protein in whole-cell extracts were quantified as before. The steadystate concentration of $B$. subtilis HemA was significantly lower if the B. subtilis bem $X$ gene was present (Table 4). It is important to note that E. coli HemA is not detectable with antisera against B. subtilis HemA (Schröder et al., 1992). Next, extracts were prepared from samples taken at different times of growth. The steady-state concentration of HemA in JM109/pHEMA2 remained essentially constant, whereas that in JM109/pHEMAX decreased further after the cells had entered stationary phase (Fig. 6). 

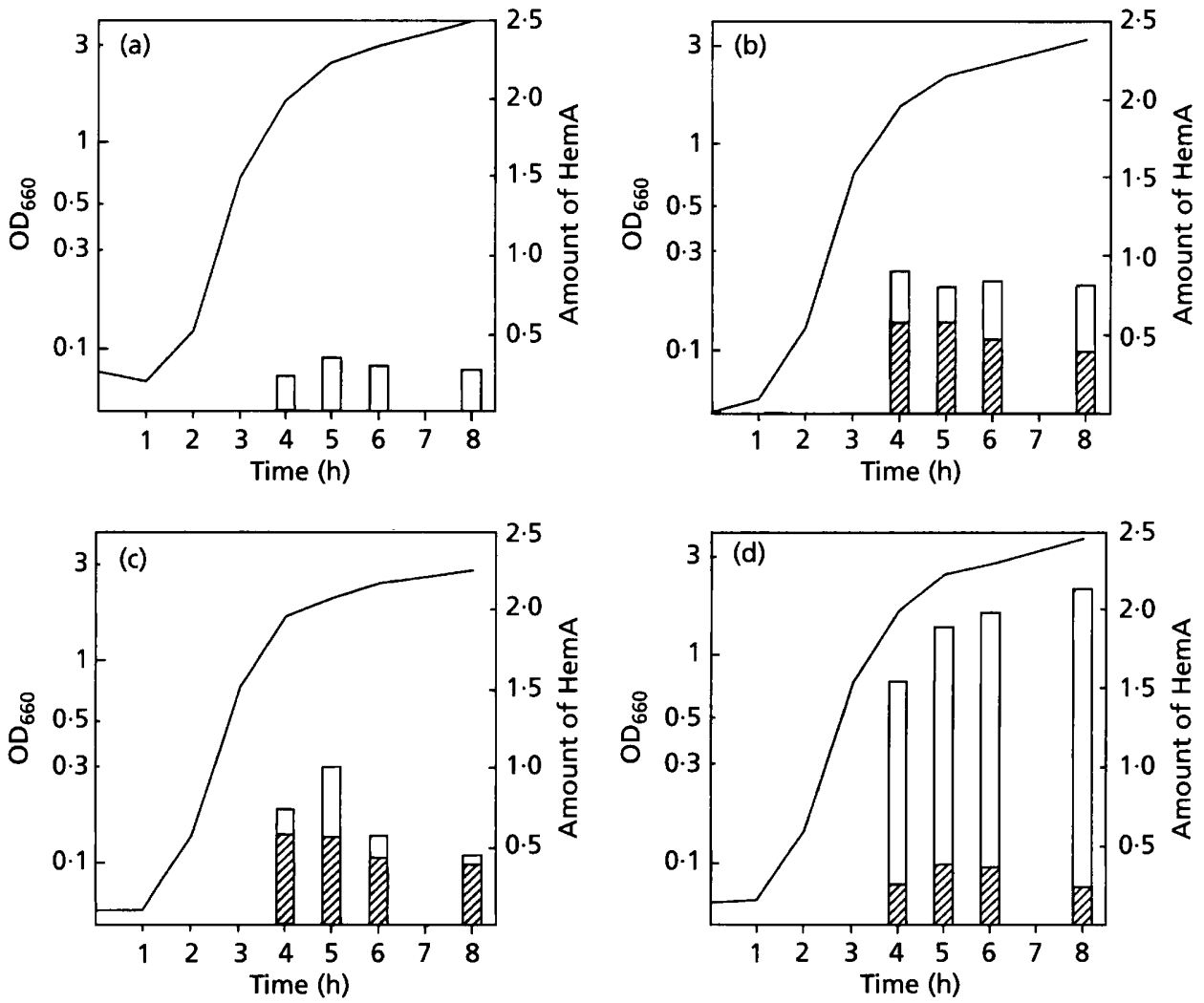

Fig. 5. Steady-state relative concentrations of HemA in different $B$. subtilis strains carrying the hemA gene or both hemA and hem $X$ on a plasmid. The $B$. subtilis strains were grown in LB supplemented with chloramphenicol; samples were taken at different times in the growth curve $\left(O D_{660}\right)$ and whole-cell extracts were prepared as described in Methods. The amount of HemA antigen per $\mathrm{mg}$ protein was analysed by rocket immunoelectrophoresis using antiserum directed against native HemA and the relative amounts are presented in the bar plot. (a) B. subtilis $3 G 18 \Delta$ HemX carrying pHP13 (open bars) or pHEMX (no HemA protein was detectable in this strain; see Table 3); (b) B. subtilis $3 G 18 \Delta$ HemX carrying pHEMA2 (open bars) or pHEMAX (hatched bars); (c) B. subtilis 3 G18 carrying pHEMA2 (open bars) or pHEMAX (hatched bars); (d) B. subtilis 3G18 $4404 R$ carrying pHEMA2 (open bars) or pHEMAX (hatched bars).

Table 4. Relative concentrations of $B$. subtilis HemA in E. coli JM109 containing the $B$. subtilis hemA and hem $X$ genes on plasmids

The E. coli strains were grown overnight in LB and cell extracts were prepared as described in Methods. The relative amount of HemA per mg total cell protein compared to that of

JM109/pHEMA2 was determined by rocket immunoelectrophoresis using antiserum directed towards native Hem A; the results are given as mean values, with standard deviations, of $n$ experiments.

\begin{tabular}{|lcl|}
\hline Plasmid(s) in E. coli JM109 & Amount of HemA & \multicolumn{1}{c|}{ hemX/HemX } \\
\hline pHEMA2 & 1 & Not present \\
pHEMAX & $0 \cdot 17 \pm 0 \cdot 02(n=3)$ & Present/intact \\
pHP13 & $<0.005(n=3)$ & Not present \\
pAHEMA2 & $0 \cdot 15 \pm 0 \cdot 05(n=3)$ & Not present \\
pAHEMA2 + pLUP513 & $<0.005(n=3)$ & Present/intact \\
pAHEMA2 + pHEMX513 & $<0 \cdot 005(n=1)$ & Present/intact \\
pAHEMA2 + pLUP515 & $0 \cdot 18 \pm 0.06(n=2)$ & Present/lacks N-terminal 17 residues \\
pAHEMA2 + pPHOA2 & $0 \cdot 17 \pm 0.06(n=2)$ & Present/HemX (residue no. 2)-PhoA \\
& & fusion protein \\
pAHEMA2 + pPHOA128 & $0 \cdot 16 \pm 0.06(n=2)$ & Present/HemX (residue no. 128)-PhoA \\
& & fusion protein \\
pAHEMA2 + pUC19 & $0 \cdot 16 \pm 0.06(n=3)$ & Not present \\
pAHEMA2 + pHP13 & $0 \cdot 18(n=1)$ & Not present \\
\hline
\end{tabular}




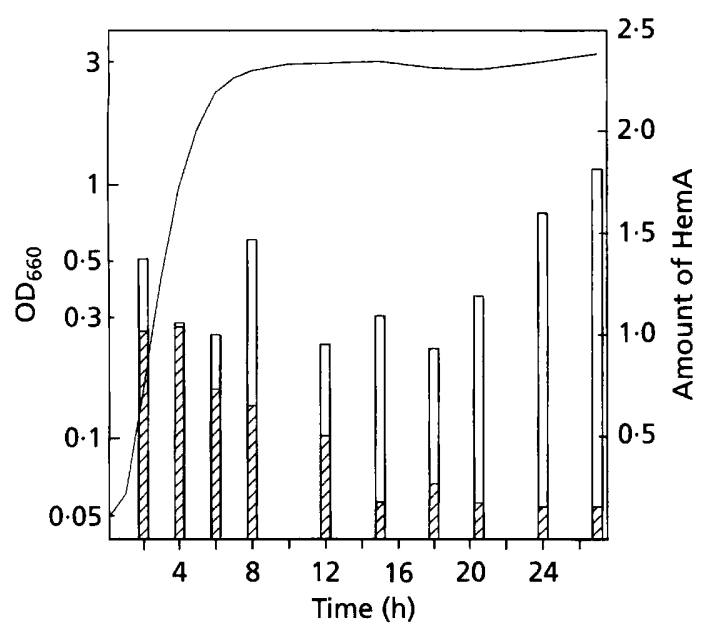

Fig. 6. B. subtilis HemA content of E. coli JM109 carrying pHEMA2 (hemA) or pHEMAX (hemAX). The $E$. coli strains were grown in LB supplemented with chloramphenicol, and samples were taken at different times in the growth curve. Cell extracts were prepared as described in Methods and analysed for relative concentrations of HemA antigen per $\mathrm{mg}$ protein by rocket immunoelectrophoresis using antiserum directed against native HemA preabsorbed with an E. coli (hemA) cell lysate (see Methods). The two $E$. coli strains showed practically identical growth curves $\left(O D_{660}\right)$. The relative amounts of HemA are shown in the bar plot: open bars, JM109/pHEMA2; hatched bars, JM109/pHEMAX.

In the above experiments bem $A$ and be $m X$ were present on the same high-copy-number vector. The bem $A$ gene of plasmid pHEMA2 was cloned into the low-copy-number vector pACYC177, resulting in pAHEMA2 (Fig. 2c). This plasmid is compatible with pUC derivatives. In $E$. coli JM109/pAHEMA2, HemA protein was found at a concentration corresponding to about $20 \%$ of that in $E$. coli JM109/pHEMA2, consistent with the copy number difference (Table 4). To study the effect of HemX on $B$. subtilis HemA expressed in E. coli JM109/pAHEMA2, we transformed this strain with plasmid pLUP513 (a derivative of pUC19 with bemX under control of the lac promoter). The resulting strain was analysed for HemA antigen. As seen in Table 4, the presence of pLUP513 caused a strong decrease of the HemA concentration. The bemX gene from pLUP513 was transferred to pHP13, resulting in pHEMX513, which was transformed into $E$. coli JM109/pAHEMA2. The effect of HemX on HemA was observed in this strain also (Table 4). To analyse if the complete B. subtilis HemX protein is needed to obtain the effect on HemA concentrations, E. coli JM109/ pAHEMA2 was transformed with pLUP515 (the first 17 amino acids of HemX deleted), pPHOA2 (encodes the HemX-PhoA fusion protein with PhoA fused to the second amino acid of HemX), and pPHOA128 (encodes the HemX-PhoA fusion protein containing 128 amino acids of HemX) (Figs $1 \mathrm{~b}$ and 2c). None of these truncated versions of hem $X$ affected the cellular concentration of HemA (Table 4).

A $\sigma^{\mathrm{A}}$-type promoter positioned 170 nucleotides upstream of $\operatorname{bem} A$ has been identified as the only (or major)

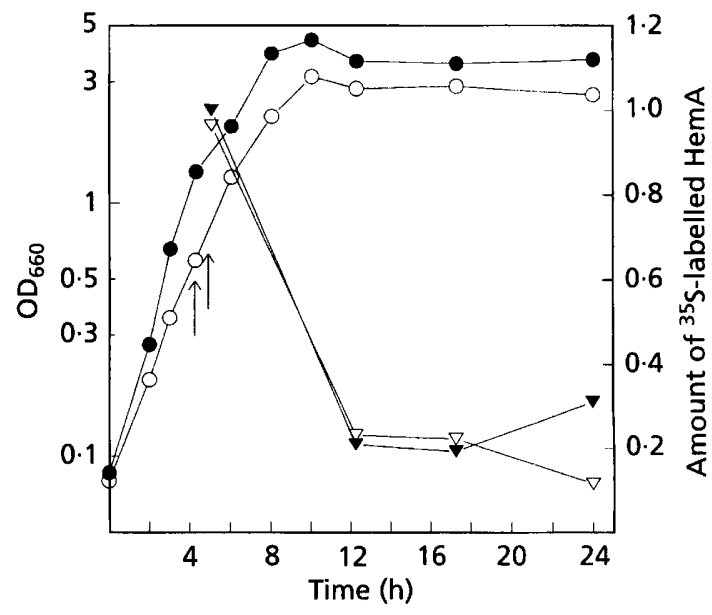

Fig. 7. Analysis of the stability of HemA protein depending on the presence of HemX. E. coli MM294 carrying pHEMA2 (filled symbols) or pHEMAX (open symbols) was grown in M63 minimal medium supplemented with chloramphenicol and 18 of the common amino acids (excluding methionine and cysteine). Growth was followed by the $\mathrm{OD}_{600}$ (circles). The cultures were pulse-labelled for $30 \mathrm{~min}$ with [ $\left.{ }^{35} \mathrm{~S}\right]$ methionine in the mid-exponential growth phase (indicated by arrows). Samples were taken at intervals from the cultures and radioactive $50 \mathrm{kDa}$ HemA (triangles) was quantified after immunoprecipitation as described in Methods. The amounts of radioactive HemA antigen in different samples are presented relative to that of the first $(5 \cdot 0 \mathrm{~h}) \mathrm{MM} 294 / \mathrm{pHEMA2}$ sample.

promoter for the bem $A$ operon (M. Petricek, unpublished data). We have constructed two bem $A$-lac $Z$ transcriptional and translational fusions containing the first 34 and 300 codons, respectively, of bem $A$. The amount of $\beta$ galactosidase produced from these fusions in $E$. coli measured both as enzyme activity and as antigen was not influenced by the presence or absence of HemX, indicating that HemX does not directly affect the activity of the $\operatorname{bem} A$ promoter or bem $A$ translation initiation (data not shown). In order to test if HemX affects the stability of the HemA protein the following experiment was done. Exponentially growing E. coli MM294 harbouring pHEMA2 or pHEMAX was pulse-labelled with $\left[{ }^{35} \mathrm{~S}\right]$ methionine and samples were taken at intervals. HemA was immunoprecipitated with an excess of specific antibodies and radioactive $\operatorname{HemA}$ was quantified as described in Methods. The results of this experiment revealed no difference in the stability of the HemA protein in the two strains (Fig. 7). Control experiments on the steady-state concentration of HemA antigen in MM294/ pHEMA2 and MM294/pHEMAX grown in supplemented M63 minimal medium gave results very similar to those shown in Fig. 6.

\section{DISCUSSION}

The B. subtilis bemX gene is located in the hem AXCDBL operon, which encodes enzymes required for the synthesis of uroporphyrinogen III from glutamyl-tRNA (Petricek et al., 1990; Hansson et al., 1991). However, bem $X$ is not 
directly involved in ALA or tetrapyrrole synthesis since deletion of the gene does not lead to a growth requirement for ALA or haemin or otherwise impair haem synthesis. Furthermore HemX mutants do not accumulate or excrete tetrapyrroles (unpublished results), as has been observed, for example, for E. coli mutants blocked in different steps of haem biosynthesis (Cox \& Charles, 1973).

We have not found any obvious similarity between the predicted amino acid sequence of the HemX protein and sequences available in databases. Some weak similarity has been observed between HemX and predicted chloroplast-encoded proteins of unknown function, e.g. the protein encoded by ORF313 of tobacco chloroplasts (Shinozaki et al., 1986). The significance of this is uncertain. Hydropathy plots of the HemX sequence show it to be a hydrophobic protein with the potential to form up to seven membrane-spanning segments. Another notable feature of $\mathrm{HemX}$ is a lysine-rich region KKKKWGK (residues 164-170) which may be functionally relevant.

bem $X$ has the potential to code for a protein of $32 \mathrm{kDa}$. However, SDS-PAGE of HemX produced in an E. coli in vitro transcription-translation system (Petricek et al., 1990 ) or in E. coli minicells expressing hem $X$ has yielded a protein of only $26 \mathrm{kDa}$. This difference probably reflects the hydrophobic character of HemX; hydrophobic proteins often show aberrant mobility in SDS-PAGE. Fractionation of E. coli minicells producing HemX reveals that the protein is located in the membrane fraction, supporting the notion that it is an intrinsic membrane protein.

We have used hemX-pho $A$ fusions (Manoil \& Beckwith, 1985) to gain some information about the topology of HemX and we have so far obtained two types of active fusions. One type had $p h o A$ fused in-frame to a position corresponding to the second amino acid of HemX. This fusion produces high amounts of hybrid protein in E. coli as shown by ALP activity measurements and the presence of a $51 \mathrm{kDa}$ protein which reacts with anti-ALP antibodies. Most of this hybrid protein was found in the periplasmic fraction and therefore it does not provide any information on HemX topology. It is however surprising that this protein is secreted since the deduced $\mathrm{N}$-terminal sequence of the fusion protein, MIADSYTQVASWTEPFPFCP (residues from HemX are underlined) does not have the features of a typical bacterial signal sequence (Von Heijne \& Abrahamsen, 1989). The other type of fusion was an out-of-frame fusion at a site corresponding to residue 128 of HemX. It produces a fusion protein of the expected size for an in-frame fusion, i.e. an ALP immunoreactive protein of $60 \mathrm{kDa}$. This protein copurifies with the membrane fraction and can be solubilized with detergent, indicating that it is a membrane protein. Similar +1 out-of-frame fusions producing active ALP have been described for E. coli glpT-pho $A$ (Gött \& Boos, 1988). Since this bem $X-p h o A$ fusion produces a fulllength $(60 \mathrm{kDa})$ hybrid protein there must be readthrough (translational slipping) in the region corresponding to amino acids $95-128$ of HemX. A +1 frame shift before residue 95 results in a stop codon at this position.
The results of the bem $X$-pho $A$ fusion experiments support a membrane localization of HemX. Since we obtained only two types of fusion variants, detailed predictions of HemX membrane topology cannot be made. However, the PhoA part of the fusion protein produced from the out-of-frame fusion is probably located on the outside of the membrane. This indicates that the predicted hydrophilic segment around residue 120 is exposed on the outer side of the cytoplasmic membrane. This would place the lysine-rich region around position 165 on the inside, in compliance with the 'positive-inside rule' (Von Heijne, 1992). Thus the hydrophobic segment containing residues 130-160 probably spans the membrane.

HemX does not seem to be directly involved in tetrapyrrole synthesis, but the present work has established that it negatively affects the steady-state concentration of B. subtilis HemA in both B. subtilis and E. coli. This in turn suggests that HemX may play a role in controlling tetrapyrrole synthesis in $B$. subtilis. HemX may act to convey information about the environment to the cell interior, but we have found no similarity between the predicted amino acid sequence of HemX and the sequences or conserved motifs of known membranespanning bacterial signal transduction proteins (Stock $e t$ al., 1990). The mechanism by which HemX affects the steady-state concentration of HemA is not understood. The rate of turnover of $\operatorname{HemA}$ does not seem to be affected by HemX, indicating that HemX influences the rate of synthesis of HemA. However, results with hem $A$-lac $Z$ fusions have not revealed an effect of HemX on the (major) bem $A$ promoter or on translation.

\section{ACKNOWLEDGEMENTS}

We thank Ursula Larsson for doing an excellent work on the localization of HemX in E. coli and for construction of $B$. subtilis $3 \mathrm{G} 18 \Delta \mathrm{HemX}$. We also thank Dr Simon P. Gough for pointing out amino acid sequence similarities and Karin Tsiobanelis for technical assistance.

This work was supported by grants from the Swedish Medical Research Council, from the Swedish Natural Science Research Council, the Crafoord Foundation and from Emil och Wera Cornells Stiftelse.

\section{REFERENCES}

Anderson, D. J. \& Blobel, G. (1983). Immunoprecipitation of proteins from cell-free translations. Methods Enzymol 96, 111-120.

Arwert, F. \& Venema, G. (1973). Transformation in Bacillus subtilis. Fate of newly introduced transforming DNA. Mol \& Gen Genet 123, 185-198.

Beale, S. I. \& Weinstein, J. D. (1990). Tetrapyrrole metabolism in photosynthetic organisms. In Biosynthesis of Heme and Chlorophylls, pp. 287-391. Edited by H. A. Dailey. New York: McGraw-Hill.

Chang, A. C. Y. \& Cohen, S. N. (1978). Construction and characterization of amplifiable multicopy DNA cloning vehicles derived from the P15A cryptic miniplasmid. J Bacteriol 134, 1141-1166.

Cox, R. \& Charles, H. P. (1973). Porphyrin-accumulating mutants of Escherichia coli. J Bacteriol 113, 122-132.

Devereux, J., Haeberli, P. \& Smithies, O. (1984). A comprehensive set of sequence analysis programs for the VAX. Nucleic Acids Res 12, 387-395. 
Dougan, G. \& Kehoe, M. (1984). The minicell system as a method for studying expression from plasmid DNA. Methods Microbiol 17, 233-257.

Elliott, T. (1989). Cloning, genetic characterization, and nucleotide sequence of the bem $A$-prf $A$ operon in Salmonella typhimurium. $J$ Bacteriol 171, 3948-3960.

Fortnagel, P. \& Freese, E. (1968). Analysis of sporulation mutants. II. Mutants blocked in the citric acid cycle. J Bacteriol 95, 1431-1438.

Fridén, H. \& Hederstedt, L. (1990). Role of His residues in Bacillus subtilis cytochrome $b 558$ for haem binding and assembly of succinate:quinone oxidoreductase (complex II). Mol Microbiol 4, 1045-1056.

Friedmann, H. C., Thauer, R. K., Gough, S. P. \& Kannangara, C. G. (1987). $\Delta$-Aminolevulinic acid formation in the archaebacterium Methanobacterium thermoautotropbicum requires $\mathrm{tRNA}{ }^{\mathrm{Glu}}$. Carlsberg Res Commun 52, 363-371.

Gött, P. \& Boos, W. (1988). The transmembrane topology of the $s n$ glycerol-3-phosphate permease of Escherichia coli analysed by pho $A$ and lacZ protein fusions. Mol Microbiol 2, 655-663.

Haima, P., Bron, S. \& Venema, G. (1987). The effect of restriction on shotgun cloning in Bacillus subtilis Marburg. Mol \& Gen Genet 209, 335-342.

Hansson, M. \& Hederstedt, L. (1992). Cloning and characterization of the Bacillus subtilis bemEHY gene cluster which encodes protoheme IX biosynthetic enzymes. J Bacteriol 174, 8081-8093.

Hansson, M., Rutberg, L., Schröder, I. \& Hederstedt, L. (1991). The Bacillus subtilis bem AXCDBL gene cluster, which encodes enzymes of the biosynthetic pathway from glutamate to uroporphyrinogenIII. J Bacteriol 173, 2590-2599.

Ish-Horowicz, D. \& Burke, J. F. (1981). Rapid and efficient cosmid cloning. Nucleic Acids Res 9, 2989-2998.

Jahn, D., O’Neill, G. P., Verkamp, E. \& Söll, D. (1992). Glutamate tRNA: involvement in protein synthesis and aminolevulinate formation in Chlamydomonas reinbardii. Plant Physiol Biochem 30, 245-253.

Levy, S. B., McMurry, L., Onigman, P. \& Saunders, R. M. (1977). Plasmid-mediated tetracycline resistance in Escherichia coli. Top Infect Dis 2, 181-206.

MacGregor, C. H. (1976). Biosynthesis of membrane-bound nitrate reductase in Escherichia coli: evidence for a soluble precursor. $J$ Bacteriol 126, 122-131.

Mandel, M. \& Higa, A. (1979). Calcium-dependent bacteriophage DNA infections. J Mol Biol 53, 159-162.

Manoil, C. \& Beckwith, J. (1985). Tnpho $A$ : a transposon probe for protein export signals. Proc Natl Acad Sci US A 82, 8129-8133.

Marmur, J. (1961). A procedure for the isolation of deoxyribonucleic acid from bacteria. $J$ Mol Biol 3, 208-218.

Neville, D. M., Jr (1971). Molecular weight determination of protein-dodecyl-sulphate complexes by gel electrophoresis in a discontinuous buffer system. J Biol Chem 246, 6328-6334.
O’Neill, G. P., Chen, M.-W. \& Söll, D. (1989). $\delta$-Aminolevulinic acid biosynthesis in Escherichia coli and Bacillus subtilis involves formation of glutamyl-tRNA. FEMS Microbiol Lett 60, 255-260.

Oh-hama, T., Stolowich, N. J. \& Scott, A. I. (1988). 5Aminolevulinic acid formation from glutamate via the $\mathrm{C}_{5}$ pathway in Clostridium thermoaceticum. FEBS Lett 228, 89-93.

Owen, P. (1981). Immunology of the bacterial membrane. In Organization of the Procaryotic Cell Membranes, pp. 73-164. Edited by B. K. Ghosh. Boca Raton, FL: CRC Press.

Pardee, A. B., Jacob, F. \& Monod, J. (1959). The genetic control and cytoplasmic expression of "inducibility" in the synthesis of $\beta$ galactosidase by E. coli. J Mol Biol 1, 165-178.

Petricek, M., Rutberg, L., Schröder, I. \& Hederstedt, L. (1990). Cloning and characterization of the bem $A$ region of the Bacillus subtilis chromosome. J Bacteriol 172, 2250-2258.

Rutberg, B., Hederstedt, L., Holmgren, E. \& Rutberg, L. (1978). Characterization of succinic dehydrogenase mutants of Bacillus subtilis by crossed immunoelectrophoresis. J Bacteriol 136, 304-311.

Sambrook, J., Fritsch, E. F. \& Maniatis, T. (1989). Molecular Cloning: a Laboratory Manual, 2nd edn. Cold Spring Harbor, NY: Cold Spring Harbor Laboratory.

Sanger, F., Nicklen, S. \& Coulson, A. P. (1977). DNA sequencing with chain-terminating inhibitors. Proc Natl Acad Sci US A 74, 5463-5467.

Schröder, I., Hederstedt, L., Kannangara, C. G. \& Gough, S. P. (1992). Glutamyl-tRNA reductase activity in Bacillus subtilis is dependent on the bem $A$ gene product. Biochem $J$ 281, 843-850.

Shinozaki, K. and others (1986). The complete nucleotide sequence of the tobacco chloroplast genome: its gene organization and expression. EMBO J 5, 2043-2049.

Spizizen, J. (1958). Transformation of biochemically deficient strains of Bacillus subtilis by deoxyribonucleate. Proc Natl Acad Sci US A 44, 1072-1078.

Stock, J. B., Stock, A. M. \& Mottonen, M. (1990). Signal transduction in bacteria. Nature 344, 395-400.

Von Heijne, G. (1992). Membrane protein structure prediction, hydrophobicity analysis and the positive-inside rule. J Mol Biol 225, 487-494.

Von Heijne, G. \& Abrahamsen, L. (1989). Species-specific variation in signal peptide design. Implications for protein secretion in foreign hosts. FEBS Lett 244, 439-446.

Von Wachenfeldt, C. \& Hederstedt, L. (1990). Bacillus subtilis holocytochrome $c-550$ can be synthesised in aerobic Escherichia coli. FEBS Lett 270, 147-151.

Yanisch-Perron, C., Vieira, J. \& Messing, J. (1985). Improved M13 phage cloning vectors and host strains : nucleotide sequences of the M13mp18 and pUC19 vectors. Gene 33, 103-119.

Received 2 July 1993; revised 1 October 1993; accepted 13 October 1993. 